\title{
DETERMINANT OF CAPITAL RATIO: A PANEL DATA ANALYSIS ON STATE-OWNED BANKS IN INDONESIA ${ }^{1}$
}

\author{
Pamuji Gesang Raharjo ${ }^{2}$ \\ Dedi Budiman Hakim \\ Adler Haymans Manurung ${ }^{4}$ \\ Tubagus Nur Ahmad Maulana
}

\begin{abstract}
Capital has an important role in maintaining safety of banks and in order to create a sound banking system. Banks are required to have a sufficient amount of capital, both to support its business expansion as well as a buffer to prevent any unexpected loss that banks might face and absorb losses arising from a variety of risks. Eventhough consists of four banks, State owned banks in Indonesia are catalystor for the banking industry in Indonesia. The failure of state-owned banks can affect the stability of Indonesian banking system. This study aims to study and analyze determinants of capital ratio of state-owned banks. Several variables have been used in previous studies to be used a proxy. The study applied panel data regression model. The capital ratio of state-owned banks is affected by asset growth (LNSIZE), equity to total liabilities ratio (EQTL), non performing loan (NPL), interest rate risk (IRR), and operational cost to operational revenue ratio (BOPO) on a different level of significance.
\end{abstract}

Keywords: Capital structure, state-owned commercial banks, panel data

JEL Classification: C23; G21; G32

1 This paper is part of a dissertation in the Management \& Business Program of Postgraduate School, Bogor Agriculture University, Indonesia

2 Student of Business \& Management Program of Postgraduate School, Bogor Agriculture University, Indonesia

3 Supervising Committee Chairman, Lecture of Postgraduate School, Bogor Agriculture University, Indonesia

4 Supervising Committee Members, Lecture of Postgraduate School, Bogor Agriculture University, Indonesia

Received: January 10th, 2014

Accepted for Publication : October 14th, 2014 


\section{Introduction}

Banking is the backbone of the Indonesian economy, since banking is still the main source of financing in order to drive the wheels of the economy and the creation of economic growth. Banks also play an important role in the allocation of public deposits funds that have been collected, both in the form of productive investment and in the form of lending to productive sectors. In addition, banks play a role in facilitating the allocation of investment risk efficiently (Diamond and Dybvig, 1983). At the macroeconomic level, bank is one of the means to transmit monetary policy (transmission belt), meanwhile at micro economic level bank is a major source of financing for businesses and individuals (Koch and Donald, 2000).

Banks' capital structure is fundamentally different from capital structure of non-financial companies, because the characteristics of the banking business and operations are different. Banks also need to have a 'buffer' in accordance with the provisions of the minimum capital requirement set by bank regulators (Saunders, 2008). Bank capital plays a very important role in maintaining safety and in order to create a sound of banking system.

Banks are required to have a sufficient amount of capital, both to support its business expansion as well as a buffer to prevent any unexpected loss that banks might face and absorb losses arising from a variety of risks that are material. Thus the purpose of minimum capital requirement is to ensure that banks keep enough capital for the risks they take. It is not possible to eliminate altogether the possibility of a bank failing, but governments want to make the probability of default for any given bank very small. By doing this, they hope to create a stable economic environment where private individuals and business have confidence in the banking systems.

Bank Indonesia as the central bank in Indonesia has been endeavored to improve the quality and quantity of bank capital of commercial banks in Indonesia. Improving the quality of bank capital is done by adjusting the terms of bank capital components and its instruments. While the increase in the quantity of capital is done by requiring banks in Indonesia to form additional capital above the minimum capital adequacy requirements based on bank's risk profile. Minimum capital requirement based on risk profile not only intended anticipate potential losses arising from risk weighted assets which has considered credit risk, market risk, and operational risk, but also to anticipate potensial losses from other risk in the future which has not yet been fully calculated in the risk weighted asset. The risk profil rating and the minimum capital adequacy requirements as stated on Table 1. 


\begin{tabular}{|c|c|c|}
\hline \multicolumn{3}{|c|}{$\begin{array}{c}\text { Table } 1 \\
\text { Risk Profile Rating and Minimum Capital Adequacy Requirements }\end{array}$} \\
\hline No. & Risk Profile Rating & $\begin{array}{l}\text { Minimum Capital Adequacy } \\
\text { Requirements }\end{array}$ \\
\hline 1 & 1 & $8 \%$ \\
\hline 2 & 2 & $9 \%$ up to $<10 \%$ \\
\hline 3 & 3 & $10 \%$ up to $<11 \%$ \\
\hline 4 & 4 or 5 & $11 \%$ up to $14 \%$ \\
\hline
\end{tabular}

In addition, commercial banks in Indonesia are also required to establish additional capital as a buffer in accordance with the criteria set by Bank Indonesia. Additional capital consists of capital conservation buffer, countercyclical buffer, and capital surcharge. Capital conservation buffer is the additional capital that serves as a buffer in the event of a loss in the period of crisis, countercyclical capital buffer is an additional function as a buffer for anticipated losses in the event of excessive credit growth that could potentially disrupt the stability of the financial system, and domestic capital surcharge for systemically important banks is the additional capital that serves to reduce the negative impact on the stability of the financial system and the economy in the event of a bank failure is a systemic impact through an increase in the bank's ability to absorb losses. The amount of additional capital to capital conservation buffer set by Bank Indonesia at $2.5 \%$ of risk weighted assets, a countercyclical buffer is set in the range of $0 \%$ up to $2.5 \%$ of risk weigthed assets and capital surcharge is set in the range of $1 \%$ up to $2.5 \%$ of risk weighted assets.

Commercial banks in Indonesia can be divided into 6 (six) groups, such as State-owned Banks (Bank Persero), National Private Commercial Banks (Bank Umum Swasta Nasional), Regional Development Banks (Bank Pembangunan Daerah), Joint Venture Banks (Bank Campuran), and Foreign Banks (Bank Asing). The group of state-owned Banks consist of Bank Mandiri, BRI, BNI and BTN. The share of state-owned banks' assets is 36.02 per cent in the end of 2012. These state-owned banks enjoy close links with Indonesia's largest companies, including state-owned enterprises. On the other hand, state-owned commercial banks assigned several objectives, such as providing credit to specific sectors, promoting the access to bank services for groups of population or regions not covered by private institutions, mitigating market failures due to the presence of asymmetric information, financing socially valuable (but possibly financially unprofitable) projects, and competing with private institutions to try to lower or at least keep at bay the costs of financial intermediation (Yeyati, 2004). The state-owned banks are required to have a sufficient amount of capital, both to support its business expansion as well as agent of development in Indonesia. 
The purpose of this research is to study and analyze the factors that influence the determinants of capital adequacy ratio of state-owned banks in Indonesia. Research variables used in this study are divided into two, namely internal factors (bank specific factors) and external factors. Internal factors consist of variables derived from the bank's performance, as reflected in the balance sheet, income statement, and other financial reports are prepared and published by the bank, while the external factors are variables that are not related to the bank's management but reflects the economic conditions that affect the operation and performance of the bank.

\section{THEORY}

\subsection{Capital Structure of the Company}

Capital structure is concerned with the manner in which a firm finances its business through mixture of equity and debt capital. There are several theories that have been developed related to the company's capital structure. David Durand in 1952 developed the theory of capital structure with net income approach. This approach suggests that the use of debt capital a firm can increase or reduce the company cost of capital.

Modigliani and Miller (1958) developed a financial theory that became the basic concept of modern capital structure theory and known as MM Theory. MM theory is ideal in theory but this theory is based on the assumption that capital markets are perfect and no corporate taxes, no bankruptcy costs, no information asymmetry and no agency costs. This theory is contradictory and can not be applied in actual conditions.

Modigliani and Miller (1958) provided the foundational impulse to the study of the capital structure problem by formally proving that, under conditions of complete, perfect and frictionless markets, a firms market value and the welfare of its security holders remain unaffected by financing decisions (Gertler 1988 and Fama 1990). This theoretical proposition carries the implications that: (1) financing and investment policies are independent; (2) internal and external financing are perfect substitutes; and (3) the specific type of the financing contractual arrangement, either equity or debt, is also irrelevant.

The MM theory is widely used by researchers as a review of theoretical and empirical studies in conducting studies and analyzes related to the company's capital structure. Furthermore, the MM theory was revised by Modligiani and Miller (1963) to include the effect of taxes on the value and cost of capital. With the corporate tax, the value of the firm can be varied in accordance with the variation of the proportion of debt because of the tax advantages (taxshield) of lending bill (Baral, 1996). MM theory then known as Irrelevancy Theory, since this theory states that the proportion of equity and debt has no effect on firm value (Manurung, 2011). In other words, value of the firm depends on the income generated by its assets, not by how the assets are financed or how the income is divided. 
Furthermore, Donaldson (1961) suggested pecking order theory which discusses order financing company. Solomon (1963) developed the theory of optimal capital structure where it is stated that the value of the company will increase up to a certain level and after that firm value tends to remain constant with moderate use of debt capital, and in turn will tend to decrease the value of the company. Stiglitz (1969), Haugen and the Papas (1971) and Rubenstein have developed a theory of capital structure is known as the trade-off models that discussed the financial distress and taxshield. Jensen and Meckling (1976) put forward the agency theory related to the value of the company because there is a conflict between the company's management (agent) and shareholders of the company (the principal).

Myers and Majluf (1984) suggest that the capital structure can help to mitigate the inefficiencies in a firm's investment programme that are caused by information asymmetris. They show that managers use private information to issue risky securities when they are overpriced. There is a pecking order of corporate financing such that firms prefer internal finance, and if internal is not sufficient and firms require external finance, they issue the cheapest security first.

The theories of the capital structure described above is static and ignores the presences of an optimal capital structure restructuring in response to the occurrence of fluctuations in the value of assets over time, or in other words, the company will always make major adjustments in response to changes in debt the company's assets. To overcome these weaknesses, Zweibel (1986) and Zechner et al. (1989) developed a dynamic capital structure theory. Zweibel (1986) states that the selection of the debt by the financial managers was voluntarily with credible owned limitations in order to develop the company in the future. Goldstein, Ju and Leland (2001) also introduced a dynamic structural model with EBIT - based models, in which the policy is based on the dynamic capital gains in the form of debt financing with tax advantages, potential bankruptcy costs, the variability of assets used, the interest rate is less risky, and the size of the recapitalization costs. Baker and Wurger (2002) published a paper on market timing and capital structure stating that the company issuing preference shares when the stock price high and bonds when stock prices are low.

\subsection{Bank Capital Structure}

Banks are simultaneously firms, financial intermediaries, and highly regulated business entities so that the form of incentive regulation imposed by rule determines a unique interaction between bank capital and behavior (Marques and Santos, 2004). In general, the decision of determining a bank's capital structure as well as the determination of capital structure on non-financial companies, but given the company's operating characteristics of different banks with different companies in other industries, the bank has a business risk and financial risk are different, so that the capital structure of banks differ from the non-financial corporate capital structure (Buser, 1981). 
Bank regulators use capital regulations to ensure that the market capital is recognized as well as regulated to constratin bank risks. The bank capital regulation is one of the determinants that affect determination of the capital ratio should be maintained by the bank. Mishkin (2000) and Ghosh et al. (2003) found that banking regulation, in this case the regulatory capital requirements affect bank's capital structure decisions. In Indonesia Based on previous studies, the bank's capital ratio is also influenced by other factors, such as asset growth, risk and profitability.

Determination of capital structure decisions are taken by the management policy of the company is affected by the owners or shareholders. Ownership structure represents a source of power that can be used to control the management or control of the company, especially in the decision-making process or in company policies. Relevance of ownership structure on capital structure can be explained through the agency cost theory, which states that managers and shareholders have an agency relationship.

Agency relationship in banking is very complex, because it involves the relationship between shareholders and bank's management as an agent, the relationship between bank and borrowers, and the relationship between bank and regulators. Thus, in addition to associated with the risk profile of the bank and the provision of additional capital criteria as defined by banking regulations set by the banking supervisory authorities, there are other determinants that may affect bank's management in determining the amount of a bank's capital adequacy ratio.

The bank's capital structure consists of voluntary capital structure and involuntary capital structure (Besanko and Kanatas, 1996; Cornett and Tehranian, 1992, and Keeley, 1989). Voluntary capital structure is that capital structure decisions are done using the determinant factors in accordance with the hypotheses used in the theory of capital structure of the company in general (theory of capital structure of the firm), whereas involuntary capital structure is that capital structure decisions made by meet and comply with the requirements of minimum capital adequacy ratio set by the regulator (regulatory capital).

In the voluntary capital structure, bank is possible to have excess capital above the minimum capital adequacy ratio of the provisions set by the regulator. There are several reasons a bank's capital ratio above the minimum capital provisions. One of them as a hedging strategy when banks require additional capital in the short term, either as a result of the worsening of the risk profile of a bank or other reasons. If the bank has a limited amount of capital or equal to the minimum capital adequacy ratio provisions, banks can only raise new capital in a short time by selling new shares, where the sale of new shares significant transaction costs or may result in a decrease in the price of bank shares, as investors and the public to know the bank was having difficulty capital. When bank capital is low, the addition of new capital will also transfer the value to the holder of fixed income securities (including government safety nets) as in classic conditions at the time the debt is too big (debt overhang) proposed by Myers (1977). 
To that end, the bank will maintain high capital ratios to avoid these problems, it is also easier for banks to maintain or increase the capital at the time the bank has a high income.

Commercial banks have deposits that are insured to protect depositors and to ensure financial stability. In order to mitigate the moral hazard of this insurance, commercial banks must be required to hold a minimum amount of capital. Banking regulators use regulatory minimum capital adequacy ratio of banks to ensure that bank capital is intended to avoid bank failures and limit the amount of risk that a bank could be taken. Nevertheless, Kahane (1977), Koehn and Santomero (1980), Kim and Santomero (1988), and Hovakimian and Kane (2000) argues that the regulatory capital adequacy ratio of the bank is not effective in limiting bank risk. Koehn, Kim and Santomero using a mean-variance framework to illustrate that strict regulation of bank capital is not intended as a substitute for risk. This is due to strict capital requirements will encourage owners and managers of banks to maximize the utility of bank capital, in particular by increasing the risky assets.

Other studies explain that factors such as government guarantees (the implicit and explicit deposit insurance, the doctrine of too big - too fail and lender of last resort support), earnings or franchise value and expected bankruptcy costs as all affecting the level of capital in banking firms. Assurance given by the government will reduce expected bankruptcy costs as the risk of default is transferred from the bank to the government. This in turn reduces the incentives for depositors to monitor banks closely. At the same time, the bank's shareholders can take advantage of the slack supervision by increasing the amount of bank loans, which can cause a decrease in the ratio of capital and earnings volatility because of the increased risk, and the transfer of risk to the lender and the guarantor (Hovakimian, Kane and Laeven, 2003). Therefore, the benefits to society from government guarantees highly depend on how effectively the bank regulators can control the behavior of banks in shifting risk management (Hovakimian, Kane and Laeven 2003).

On the other hand, Berger, Herring and Szegö (1995) stated that although the banks are in a business environment that is not regulated and the absence of a government bailout, banks still have to maintain capital due to the demands of the market, which is called the capital adequacy of the market (market capital requirement). Because of the failure of a bank could cause instability in the banking system, then capital is critical for the management of the bank and should be regulated by a banking supervisory authority.

In Indonesia, Yudhistira (2003) examined the impact of bank capital requirements by a simple model of the banking firm. The study results indicate that the regulatory capital took part in the change of behavior of banks in Indonesia. This study suggests that the impact of capital regulation on bank behavior and likewise have a possible effect on the economy. Tumiwa et al. (2013) found that the variation in changes in banks' capital structure decisions explained by banking regulations and good risk management practices. 


\section{METHODOLOGY}

This study is based on secondary data obtained from the quarterly publication of financial statements of all Indonesia state-owned banks, Indonesian Banking Statistic issued by Bank Indonesia on a monthly basis, and other publications during the period of the first quarter of 2004 to the fourth quarter of 2012. The data collected are then arranged in a panel data, namely a fusion between the dimension of time (time series) and the data state-owned banks (cross secton) so that it can provide a lot more information is needed in this study. Data panel also has the advantage mainly because it is robust to some violations of the Gauss Markov assumptions, namely heteroskedasticity and normality (Wooldridge, 2010). In addition, by using panel data can provide detailed information that helps in studying the behavior of each bank are examined over time and across space (Baltagi, 2005; Gujarati, 2003).

As of the end of 2012 there were 120 banks operating in Indonesia and grouped into the state-owned commercial banks, the foreign exchange national private banks, the non foreign exchange national private banks, joint venture banks and foreign banks. This study analyzes the determinants of state-owned commercial banks capital ratio. Although only consists of four banks, namely Bank BRI, Bank Mandiri, Bank BNI, and Bank BTN, but state-owned banks have a market share of $36.02 \%$ of assets, the market share of savings deposits amounted to $27.25 \%$, and the market share of the credit for $35.29 \%$ of total assets, third party funds and loans of all commercial banks in Indonesia in December 2012.

This study examined the effect of bank specific variables on capital adequacy ratio by using a multivariate panel regression model. Based on both theoritical and empirical literature reviewed, this model to find the determinants of bank capital level $i$ at time period $t$ as a function of a variety of specific variables. In order to see whether the identified bank specific variables could explain capital adequacy ratio (CAR), the multivariate panel regression model is formed:

\section{$\mathrm{CAR}_{\mathrm{it}}=\beta_{0}+\beta_{1} \mathrm{LNSIZE}_{\mathrm{it}}+\beta_{2} \mathrm{NIM}_{\mathrm{it}}+\beta_{3} \mathrm{EQTL}_{\mathrm{it}}+\beta_{4} \mathrm{NPL}_{\mathrm{it}}+\beta_{5} \mathrm{IRR}_{\mathrm{it}}+\varepsilon_{\mathrm{it}}$}

where is:

CARit : Capital ratio of bank $i$ at time $t$

LNSIZEit : Natural logarithms of total assets growth of the bank $i$ at time $t$

NIMit : Net interest margin of bank $i$ at time $t$

EQTLit : Total equity to total liabilities ratio of the bank $i$ at time $t$

NPLit : Non performing loan ratio of bank $i$ at time $t$

IRRit : Interest rate risk of bank $\mathrm{i}$ at time $\mathrm{t}$

In the above equation $\beta_{0}$ is constant and $\beta$ is coefficient of variables while $\varepsilon_{i t}$ is the residual error of the regression. 
Each variable and study its effect on the state-owned bank capital ratios are expected according to the results of previous studies can be described as the following:

\section{Dependent Variable - Capital Adequacy Ratio (CAR)}

In this study, the bank's capital adequacy ratio (CAR) is a dependent variable. CAR is one important aspect in view of the health of a bank, because the bank's capital through the ability to develop their business and as a ' buffer' to absorb losses. Given the observation period of this study is the first quarter of 2004 to the fourth quarter of 2012, the minimum capital adequacy ratio used in this study are still using the definitions contained in the Bank Indonesia Regulation No. 10/15/PBI/2008 dated 24 September 2008, the minimum capital requirement is $8 \%$ of risk-weighted assets (RWA). Bank capital is the sum of core capital (Tier 1 capital), supplementary capital (Tier 2 capital), and additional supplementary capital (Tier 3 capital) after taking into account certain factors that become deduction from capital in accordance with Bank Indonesia. RWA calculated consists of credit risk, market risk, and operational risk. Thus CAR equations used are as follows:

In accordance with Bank Indonesia regulations, banks are required to provide core capital (Tier 1 capital) at least $5 \%$ of risk weighted assets, which consist of paid-in capital, additional capital reserves (reserve disclosed), and innovative capital (innovative capital instruments). The additional supplementary capital (Tier 3 capital) can be used for market risk only, but should not exceed $250 \%$ of core capital which allocated to market risk, and the amount of supplementary capital (Tier 2 capital) and supplementary capital additional capital maximum $100 \%$ of core capital (Tier 1 Capital). Capital adequacy ratios used in this study are as stated in the financial statements of each period for each state-owned bank.

\section{Independent Variables}

There are five operational variables in accordance with previous literature selected and used

$$
\text { Car }=\frac{\text { Tier } 1 \text { Capital + Tier } 2 \text { Capital + Tier } 3 \text { Capital - Deduction Factor of Capital }}{\text { Total Risk Weighted Asset }}
$$

in this study. Overall the operational variables are internal variables. Internal variables are obtained and processed quarterly publication of the financial statements of each Stateowned banks. Explanation of each operating variable as follows:

\section{a. Natural logarithm of bank total asset (LNSIZE)}

The bank's assets can be used as a proxy of the size of the bank. The Bank size is a variable that is used to measure economic scale of the bank. The size of the bank may have an influence on the amount of bank capital. To capture the impact of bank size on the amount of capital, then used the logarithmic growth of total bank assets.

In accordance with previous research hypothesis, banks high income tend to cause the bank to diversify and have greater investment opportunities, thereby reducing the cost 
of capital and provide incentives for large banks to increase the amount of equity capital in order to avoid taking a huge risk.

On the other hand, the ease of access to the capital markets in conjunction with the policy of the bank rescue program by the government could lead to major banks maintain less capital and capital adequacy ratios are lower than smaller banks. Thus, the coefficient of bank size can be positive or negative influence on bank capital.

This study uses logarithm of total assets (LNSIZE) as a proxy of the size of the bank as used Demirguc-Kunt et al. (2004). The formula use in calculating the growth of the bank's assets as follows:

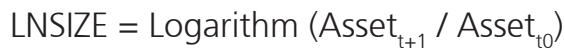

\section{b. Non performing loan (NPL)}

NPL ratio is one of the key indicators that can be used in assessing the performance and quality of bank assets. The NPL ratio shows the ability of bank management in managing problem loans. Thus, the higher the NPL ratio indicates the worse the quality of bank credit and the amount of credit risk faced by banks are getting bigger and the impact on the bank's earnings (Nasser, 2003). Non performing loans are loans classified as substandard, doubtful and loss. NPL is calculated with the following formula:

NPL $=$ (Non Performing Loans / Total Loans) $\times 100 \%$

Non performing loans in this study are as stated in the financial statements of each period for each state-owned bank.

\section{c. Net interest margin (NIM)}

Another important determinant of CAR is the quality of bank management, which is proxied by net interest margin (NIM). NIM is used to measure the ability of management to generate net interest income. NIM is the cost of financial intermediation, and is defined as net interest income divided by average earning assets of the bank. Net interest income is the interest income minus interest expense, while the productive assets of the bank in accordance with Bank Indonesia regulations concerning Commercial Bank Asset Quality Rating is the provision of bank funds to earn income, in the form of loans, securities, interbank placements, bill acceptances, bills securities purchased under agreements to resell (reverse repurchase agreement), derivative receivables, investments, balance sheet transactions and other forms of provision of funds that can be equated with it.

NIM has a positive influence on bank capital due to the high revenues allow the bank to raise additional capital through retained earnings and gave a positive signal to the value of the company (Rime, 2001). On the other hand, with high incomes may mean 
lower bank probabilitas failure (Yu, 1995). As a result, high income led to the bank's management reduce "capital cushion" given the low risk of failure. Therefore, the coefficient NIM can also have a negative relationship.

NIMs in this study are as stated in the financial statements of each period for each stateowned bank.

\section{d. Equity to total liabilities ratio (EQTL)}

The ratio of total equity to total liabilities (EQTL) is used as a proxy amount of leverage. A high EQTL signifies low leverage (low debt/liabilities), and reverse low EQTL reflects high leverage (high debt/liabilities). Banks that have high leverage (low EQTL) may find it difficult to raise new capital. Thus, banks tend to have a high equity and low leverage. EQTL expected to have a positive relationship to bank capital ratio.

\section{e. Interest rate risk (IRR)}

The main activity of the bank is to collect funds and distribute it in the form of loans. Net interest income is the lifeblood of a bank's business and it is a major target of bank's management. In bank's assets and liabilities management inherent interest rate risk, ie the risk of losses associated with the sensitivity of net income and fair value of the portfolio of the bank as interest rate movements and maturity gap between the assets and liabilities of the bank

Interest income and interest costs are affected by changes in interest rates. Since differences in the sensitivity of interest rates changes on productive assets and sources of bank funds, the impact of interest changes on interst income and interest costs are not the same. The difference in the sensitivity of changes in interest rate will affect the bank's net interst income. And if the bank's net interest income to be negative, it will erode bank capital.

Interest rate risk in this study were calculated using the following formula:

$\mathrm{IRR}_{\mathrm{it}}=$ Productive Asset $_{\mathrm{it}} /$ Liabilities $_{\text {it }}$

where is:

IRR

= Interest Rate Risk

Productive Assets = Bank's Total Productive Asset equity to total aset

Liabilities = Bank's source of funds. 


\section{RESULT AND ANALYSIS}

\subsection{Correlation Analysis}

Before performing descriptive analysis, first tested the correlation between the variables consisting of Capital Adequacy Ratio (CAR), asset growth (LNSIZE), the ratio of non-performing loans (NPLs), net interest margin (NIM), the ratio of equity the bank's liabilities (EQTL), and interest rate risk (IRR) as presented in Table 2.

From Table 2, it was known that the NPL had the strongest positive correlation with CAR (0.5862). The other independent variables had a significant positive correlation with the CAR are the ratio of equity to total bank liabilities (EQTL) and interest rate risk (IRR). On the other hand, net interest margin (NIM) and total equity to total liabilities (EQTL) have a positive correlation with bank's asset growth (LNSIZE).

\begin{tabular}{c|c|c|c|c|c|c}
\multicolumn{7}{c}{ Table 2 } \\
& CAR & LNSIZE & NPL & NIM & EQTL & IRR \\
\hline CAR & 1.0000 & & & & \\
\hline LNSIZE & -0.2399 & 1.0000 & & & & \\
\hline NPL & 0.5862 & -0.2153 & 1.0000 & & & \\
\hline NIM & -0.1782 & 0.1692 & -0.3053 & 1.0000 & & \\
\hline EQTL & 0.1197 & 0.0001 & -0.0751 & 0.3135 & 1.0000 & \\
\hline IRR & 0.0733 & -0.2090 & -0.3977 & 0.0436 & 0.4590 & 1.0000 \\
\hline Source: data processed & & & & \\
\end{tabular}

\subsection{Descriptive Statistic}

Summary of descriptive statistics for each variable during the observation period for stateowned banks were used in this study can be seen full in Table 3. From Table 3, it was known that the level of capital adequacy ratio of state owned banks always above the minimum capital requirement set by Bank Indonesia (8\%) during the period of the first quarter of 2004 to the fourth quarter of 2012. The lowest capital adequacy ratio was $12.02 \%$ and the highest was $27.81 \%$ with an average capital adequacy ratio was $17.50 \%$.

During the same period, the lowest asset growth rate was $-12.21 \%$ and the highest was $21.65 \%$ with average asset growth was $3.42 \%$. The lowest ratio of non-performing loans (NPLs) of state owned banks was $1.74 \%$ and the highest was $27.66 \%$ with an average 
of $6.24 \%$, while the net interest margin (NIM) of $3.81 \%$ lowest and highest $12.36 \%$. On the other hand, the lowest risk index of state-owned banks is 7.59 and the highest is at 45.64, with an average of 19.68 .

\begin{tabular}{l|c|c|c|c|c|c|c|c|c}
\multicolumn{7}{c}{ Tabel 3. } \\
\begin{tabular}{l|c|c|c|c|c|c|c} 
Descriptive Statistic \\
Iariable
\end{tabular} & Obs. & Min. & Max. & Mean & $\begin{array}{c}\text { Std. } \\
\text { Dev. }\end{array}$ & Skewness & Kurtosis & $\begin{array}{c}\text { Jarque - } \\
\text { Bera }\end{array}$ & Prob. \\
\hline CAR & 144 & 0.1202 & 0.2781 & 0.1750 & 0.0327 & 1.0261 & 3.5464 & 27.0617 & 0.0000 \\
\hline LNSIZE & 144 & -0.1221 & 0.2165 & 0.0342 & 0.0525 & 0.3525 & 3.7567 & 6.4181 & 0.0404 \\
\hline NPL & 144 & 0.0174 & 0.2766 & 0.0624 & 0.0540 & 2.5104 & 8.9427 & 363.1452 & 0.0000 \\
\hline NIM & 144 & 0.0381 & 0.1236 & 0.0661 & 0.0235 & 1.1780 & 2.9397 & 33.3252 & 0.0000 \\
\hline EQTL & 144 & 0.0408 & 0.1619 & 0.1054 & 0.0269 & -0.2038 & 2.9183 & 1.0364 & 0.5956 \\
\hline IRR & 144 & 0.9035 & 1.4383 & 1.0678 & 0.0727 & 1.3220 & 7.8717 & 184.3417 & 0.0000 \\
\hline
\end{tabular}

Source: data processed

\subsection{Determinants of Capital Adequacy Ratio}

One goal of this study was to analyze the factors that affected on the capital adequacy ratio of state-owned banks in Indonesia. The Analysis uses a panel data regression. Then it will be tested in order to determine the appropriate panel data models between the fixed effect model (FEM) and the random effect model (REM).

Testing and determination of appropriate panel data model are done by using the Chowtest, Lagrange Multiplier test (LM-test), and the Hausman test. Chow-test is done by comparing the Pooled Least Squares (PLS) with Fixed Effect Model. Chow-test assumes the error terms in the regression will be normally distributed with the same variance $\left(\sigma^{2}\right)$. If the value of Chow Statistic (F.stat) generated from the test is greater than the F-table, the null hypothesis is rejected so that the model chosen for use is Fixed Effect Model, and vice versa. LM-test is done by comparing the PLS with REM, while the Hausman-test is done by comparing the FEM with REM.

From the results of the Chow test and the Hausman test using STATA application show that the model is best used FEM. This is in line with Nachrowi and Usman (2006) which states that if the data panels have held a greater amount of time than the number of individuals observed, it is advisable to use the FEM. Table 4 shows the complete results data processing using a data panel fixed effect model to analyze the factors that affected on the capital adequacy ratio of state-owned banks in Indonesia. 
From Table 4, it was known that the coefficient of determination (R-squared) of 53,97\%. It states that the variation of variables (LNSIZE, NPL, NIM, EQTL, and ZRISK) can explain variation CAR only $53.97 \%$, while $46.03 \%$ is explained by other variables. These results also explain that a lot of variables that describe the state-owned bank's capital ratio is not included in this study.

\begin{tabular}{|c|c|c|c|c|}
\hline \multicolumn{5}{|c|}{$\begin{array}{c}\text { Tabel } 4 . \\
\text { Panel Regression Model }\end{array}$} \\
\hline Variabel & Coef. & SE & t-stat. & Prob. \\
\hline C & 0.1555 & 0.0433 & 3.5888 & 0.0005 \\
\hline LNSIZE & -0.1008 & 0.0381 & -2.6435 & 0.0092 \\
\hline NPL & 0.3899 & 0.0418 & 9.3360 & 0.0000 \\
\hline NIM & 0.3763 & 0.2646 & 1.4224 & 0.1572 \\
\hline EQTL & 0.5086 & 0.1023 & 4.9692 & 0.0000 \\
\hline IRR & -0.0748 & 0.0346 & -2.1595 & 0.0326 \\
\hline R-square & 0.5549 & \multicolumn{2}{|l|}{ Mean dependent var } & 0.1750 \\
\hline Adjusted R-squared & 0.5285 & \multicolumn{2}{|l|}{ S.D. dependent var } & 0.0327 \\
\hline S.E. of regression & 0.0224 & \multicolumn{2}{|l|}{ Akaike info creation } & -4.6960 \\
\hline Sum squared resid & 0.0679 & \multicolumn{2}{|l|}{ Schwarz criterion } & -4.5104 \\
\hline Log likelihood & 347.1145 & \multicolumn{2}{|l|}{ Hannan-Quin criter. } & -4.6206 \\
\hline F-statistic & 21.0394 & \multicolumn{2}{|l|}{ Durbin-Watson stat } & 0.6967 \\
\hline Prob(F-statistic) & 0.0000 & & & \\
\hline
\end{tabular}

The model shows that the growth of bank total assets has a negative effect on stateowned bank capital ratio and statistically significant at the 0.05 level. This means that each additional $1 \%$ of the bank's assets led to the bank's capital ratios decreased by $0.08 \%$. The growth of the bank's assets are mainly due to the productive assets of bank increased, both in the form of loans or investments in other risky assets. Along with the growth in the number of loans and risky financial instruments that will enhance the bank's potential losses due to bad debts and losses due to declining prices of financial instruments held by banks. In accordance with the regulation of bank capital, the addition of loans and financial instruments that led to the bank's risk weighted assets will increase and the bank's capital adequacy ratio will decrease. This is inline with research conducted by Kane (2000) and Mishkin (2006) who obtain a negative relationship between the size and the capital ratio. From a safety net perspective (systemic risk) larger banks can viewed as 'Too-Big-To-Fail' or "Too-Big-To-Discipline-Adequately. On other 
hand, Rime (2001) stated that bank's size has a negative and significant impact on capital, indicating that the big banks increased their capital less than other banks.

High non performing loan or impaired loans (NPL) are commonly associated with high risk and poor management (Barrios and Blanco, 2003). The result show that the variable NPL is statistically significant at the 0.01 level and has a positive effect on bank capital ratio. This indicates that the increase in potential problem loans losses anticipated by the management of state-owned banks to raise capital to absorb potential losses. This is inline with study conducted by Ahmad et al. (2009).

The variable net interest margin (NIM) has a positive coefficient but it is not statistically significant. This finding indicates that state owned banks in Indonesia have been very profitable, they retained a lot of earnings and capital ratios passively rose. The result is inline with study conducted by Rime (2001), whereas interest margin (NIM) has a positive influence on bank capital due to the high revenues allow the bank to raise additional capital through retained earnings and gave a positive signal to the value of the company. This finding consistent with the view a high earnings/franchise value provides bank managers easy access to equity capital and self-regulatory incentives to minimize risk taking (Cebenoyan et al. 1999; and Saunders and Wilson 2001). This finding is inconsistent with the empirical findings on the Malaysian banks in study conducted by Ahmad et al. (2009).

The ratio of equity to total bank liabilities (EQTL) is statistically significant at the 0.01 level and has a positive effect on state-owned bank capital ratio. This finding indicate that state owned banks in Indonesia tend to have high capital and low leverage to keep the bank had no difficulty in raising capital, either at the time of loan expansion when the economy is booming or absorb losses during a recession. The positive sign of EQTL indicates a negative relationship between bank leverage and the risk-weighted capital adequacy ration (Ahmad et al. 2009). On the other hand, the variable interest rate risk (IRR) is statitically significant influenced the state-owned banks capital ratio at 0.05 . The coefficient of IRR shows that a one unit increase in interest rate risk gives decline a 0.07 unit in bank's capital adequacy ratio.

\section{CONCLUSION}

In line with the experience in other economies and consistent with finding literature, the capital ratio level of state owned banks in Indonesia is determined by a number of factors. The variables that statistically significant affect the capital ratio of state-owned banks in Indonesia are asset growth (LNSIZE), the amount of non-performing loans (NPL), interest rate risk (IRR), and the ratio of equity to total bank liabilities (EQTL), and net interest margin (NIM), meanwhile net interest margin (NIM) did not significantly affect the capital adequacy ratio.

The additional capital regulation aims to improve the readiness of Indonesia commercial banks in anticipation of increased risk and surprises in the future due to fluctuations in 
macroeconomic conditions. Changes in the bank capital ratio regulation must be followed by micro-prudential (individual bank) supervision. It is intended to prevent the bank's management to invest in high risk assets to offset the additional cost of capital.

This study only examines the determinants of capital adequacy ratio of state-owned banks in Indonesia, and because of differences in the business characteristics, incentives and organization structure, consequently the results of this study still needs to be reviewed when used on other bank groups, including banking in other countries, especially those that have a different interest rate sensitivity and different banking regulations. 


\section{REFERENCES}

Ahmad, R., Ariff, M., and Skully, M.J. (2009). The Determinants of Bank Capital Ratios in a Developing Economy. Asia-Pacific Finan Markets 15:255-272.

Baker, Malcom, and Jeffrey Wurgler. (2002), Market Timing and Capital Structure. Journal of Finance 57, 1-32.

Baltagi, B. H. (2005). Econometric Analysis of Panel Data, Chichester: John Wiley and Sons.

Baral, Keshar Jung. (1996), Capital Structure and Cost of Capital in Public Sector Enterprises in Nepal. Ph.D thesis. Delhi University.

Barrios, V.E.J. and Blanco, J. (2003). The Effectiveness of Bank Capital Adequacy Regulations: An Empirical Approach. Journal of Banking and Finance, 27, pp.1935-1958.

Berger, A., DeYoung, R., Flannery, R., Lee, D., and Oztekin, O. (2008). How Do Large Banking Organizations Manage Their Capital Ratios?. The Federal Reserve Bank of Kansas City, Research Working Paper 08-01.

Berger, A.N, Herring, H.J., and Szego G.P. (1995). The Role of Capital in Financial Institutions. Wharton School Center for Financial Institutions, Working Paper 95-01.

Besanko, D. and Kanatas, G. (1996). The Regulation of Bank Capital: Do Capital Standards PromoteBank Safety?. Journal of Financial Intermediation. 5, 160-183.

Buser, Stephen A., Andrew H. Chen, and Edward J. Kane. (1981). Federal Deposit Insurance, Regulatory Policy, and Optimal Bank Capital. The journal of Finance, 36 (1), 51-60.

Cebenoyan S., Cooperman ES., and Register CA. (1999). Ownership Structure, Charter Value, and Risk-taking Behavior of Thrifts. Financial Management. 26, 43-60. doi: $10.2307 / 3666116$

Cornett, M. M. and H. Tehranian. (1992). Changes in Corporate Performance Associated with Bank Acquisitions. Journal of Financial Economics. 31, 211-234.

De Bondt, G.J, and Prast.H.M. (2000). Bank Capital Ratios in the 1990s: Cross-country evidence. Banca Nazionale del Lavoro Quarterly Riview, 53(212):71.

Demerguc-Kunt A., L. Leaven and R. Levine (2003), The Impact of Bank Regulation, Concentration and Institution on Bank Margin, National Bureau of Economic Research. Working Paper 9890. 
Diamond and Dybvig (1983). Bank Runs, Deposit Insurance, and Liquidity. The Journal of Political Economy, Vol. 91, No. 3, pp. 401-419.

Donaldson, G. (1961), Corporate Debt Capacity. Harvard University Press, Boston.

Durand, David. (1952), Cost of Debt and Equity Funds for Business: Trends and Problem Measurement. Conference on Research in Business finance. The National Bureau of Economic Research. p. 215-262.

Ediz, T., I. Michael, and W. Perraudin (1998). The impact of capital requirements on U.K. bank behaviour. Federal Reserve Bank of New York Economic Policy Review, October 1998.

Fischer, Edwin O., Robert Heinkel, and Josef Zechner, 1989, Dynamic Capital Structure Choice: Theory and Tests, Journal of Finance 44, 19-40.

Furlong, F. T. and Keeley, M.C. (1989). Capital Regulation and Bank Risk-Taking: A Note. Journal of Banking and Finance 13 (6): 883-91.

Goldstein, Ju and Leland H. (2001). An EBIT-Based Model of Dynamic Capital Structure. Journal of Business, vol. 74, no. 4, pp.483-512.

Gujarati, D. N. (2003). Basic econometrics. New York, USA, McGrawHill.

Hanan, T.H. and Hanweck, G.A. (1998). Bank Insolvency Risk and the Market for Large Certificates of Deposit. Journal of Money Credit and Banking, Vol.20, No.20.

Hovikimian, A., and E. Kane. (2000). Effectiveness of Capital Regulation at U.S. Commercial Banks, 1985 to 1994. Journal of Finance 55: 451-469.

Hovikimian, A., E. Kane, and L. Laeven. (2003). How Country and Safety-Net Characteristics Affect Bank Risk-Shifting. Journal of Financial Services Research 23: 177-204.

Jacques, K. and P. Nigro (1997). Risk-based capital, portfolio risk, and bank capital: A simultaneous equations approach. Journal of Economics and Business 49: 533-547.

Jensen, Michael C. and William H. Meckling. 1976. Theory of the Firm: Managerial Behavior, Agency Costs and Ownership Structure. Journal of Financial Economics 3: 305-360.

Kane, E.J. (2000). Incentives for banking megamergers: What motives might regulators infer from event study evidence?. Journal of Money, Credit and Banking 32, 671-701.

Kahane, Y. (1977). Capital Adequacy and the Regulation of Financial Intermediaries. Journal of Banking and Finance 1, 207-218.

Kaufman G.G. (1991). Capital in Banking: Past, Present, and Future. Journal of Financial Service Research 5: 385-402.

Kim, D., and A. M. Santomero. (1988). Risk in Banking and Capital Regulation. Journal of Finance 43 (5): 1219-33 
Koch TW and Mac Donald SS. (2000), Bank Management. Fourth Edition. Orlando. The Dryden Press. Harcourt Brace College Publishers.

Koehn, M. and A. M. Santomero (1980). Regulation of Bank Capital and Portfolio Risk, Journal of Finance 35, 1235-1244.

Manurung, Adler H. (2011), Metode Penelitian: Keuangan, Investasi, dan Akuntansi Empiris. PT. Adler Manurung Press.

Mishkin, F.S. (2006). How Big A Problem Is Too Big To Fail?. Journal of Economic Literature 44, 988-1004.

Modigliani, F, and Miller, M.H. (1958). The Cost of Capital, Corporation Finance, and the Theory of Investment. American Economic Review Vol.XLVIII, No.3, (June 1958), pp.26197, reprinted in The Theory of Business Finance (2e), Stephen H. Archer and Charles A. D'Ambrosio, eds., New York, Macmillan, 1976 (page references to reprint).

Modigliani, Franco and Merton Miller (1963). Corporate Income Taxes and the Cost of Capital: A Correction. American Economic Review, vol.53, pp. 433-443

Myers, S. C. (1977). Determinants of Corporate Borrowing. Journal of Financial Economics, 5 , 147-175.

Myers, S.C. and Majluf, N.S. (1984). Corporate Financing and Investment Decisions When Firm Have Information That Investors Do Not Have. Journal of Financial Economics 13, pp. 187-221.

Nasser, Etty M. (2003). Perbandingan Kinerja Bank Pemerintah dan Bank Swasta Dengan Rasio CAMEL Serta Pengaruhnya Terhadap Harga Saham. Media Riset Akuntansi, Auditing dan Informasi, Vol. 3, No. 3.

Nachrowi ND, Usman H. (2006). Pendekatan Populer dan Praktis Ekonometrika Untuk Analisis Ekonomi dan Keuangan. Lembaga Penerbit Fakultas Ekonomi Universitas Indonesia.

Rime, B. (2001). Capital Requirements and Bank Behaviour: Empirical evidence for Switzerland. Journal of Banking and Finance 25: 789-805.

Saunders A., and Wilson B. (2001). An Analysis of Bank Charter Value and Its Riskconstraining Incentives. Journal of Financial Sevices Research, 19, 185-195. doi: 10.1023/ A: 1011163522271

Solomon, Ezra. (1963). The Theory of Financial Management. New York: Columbia University Press.

Stiglitz, J.E. (1969). A Re-Examination of the Modigliani-Miller Theorem. American Economic Review, 59:5, pp. 784-793.

Tumiwa RAF, Sudarma M, Salim U, and Djumahir. 2013. Banking Regulation, Risk Management, 
and Capital Structure Decisions: A Study on Rural Banks in Indonesia. Research Journal of Finance and Accounting, 4(15): 27-35.

Wooldridge, J.M. (2010). Econometric Analysis of Cross Section and Panel Data. $2^{\text {nd }}$ Edition. MIT Press.

Yu, H. (1995). The Determinants of Interest Rate Margins: Empirical Evidence on the Canadian Banking Industry. International Journal of Finance, 7: 33-45

Yudhistira, D. (2003). The impact of Bank Capital Requirement in Indonesia. Available: http://129.3.20.41/eps/fin/papers/0212/02122002.pdf

Zwiebel, J. (1996). Dynamic Capital Structure under Managerial Entrenchment. American Economic Review 86 (5), 1197-1215. 